\title{
Physical capability in a rural birth cohort at the age of 52: association with early environmental, nutritional, and developmental factors
}

Pedro Arroyo ${ }^{1}$, Marcelino Esparza-Aguilar2 ${ }^{2 *}$, Verónica Martín-Martín ${ }^{3}$, Juan Carlos Gomez-Verjan", Lorena Parra-Rodríguez ${ }^{5}$, Cinthya Cadena-Trejo ${ }^{1}$, Cecilia Salazar-Pérez ${ }^{6}$ and Luis Miguel Gutiérrez-Robledo ${ }^{7}$

\begin{abstract}
Introduction: Midlife physical capability (PC) is associated with developmental factors in the populations of economically developed countries. As far as we know, there is no information for rural populations of low- and middleincome countries. The aim of the study was to investigate the influence of pre- and postnatal factors on midlife objective measures of PC in a 1966-67 birth cohort from a Mexican rural community. The hypothesis was that adverse developmental conditions are associated with low midlife PC.

Methods: In 1966-67, a birth cohort of all children from a poor Mexican rural community was assembled. Data on family socioeconomic status (SES), parental health and nutritional status, birth weight, postnatal growth and feeding patterns were registered. In 2018, out of the 336 cohort members, 118 were living in the community, and eighty-two of them underwent a comprehensive clinical evaluation. The evaluation included grip strength, gait velocity and chair-stand PC tests. In multivariable linear models, PC tests were the dependent variables, and prenatal, birth and postnatal factors were the independent variables. Adjustment for confounding was made with adult anthropometric, body composition, clinical and ageing status variables.

Results: Independent of adult health status and other ageing indicators, lower PC was associated with family organization and SES, parental nutritional status, birth weight, infant postnatal growth velocity, and weaning time. These results indicate that adverse family and environmental conditions that are prevalent in poor rural communities are associated with low midlife PC.
\end{abstract}

Keywords: Developmental origins, Maternal malnutrition, Infant malnutrition, Adult physical capability, Accelerated ageing

*Correspondence: inp.investigacion.epidemio@gmail.com

${ }^{2}$ Research Unit of Epidemiology, Direction of Research, Instituto Nacional de Pediatría, Insurgentes Sur 3700, Letra C, Alcaldía Coyoacán, C.P. 04530 Ciudad de México, México

Full list of author information is available at the end of the article

\section{Introduction}

Several investigations have confirmed that exposure to adverse environmental conditions during periods of growth and development is related to adult chronic pathological conditions and age-associated diseases. One of the main identified factors is maternal undernutrition [1]. This association has been explained by the concept of "developmental programming by early-life 
undernutrition" [2]. The evidence of this relationship comes from studies of populations exposed to prenatal famine episodes and adult health outcomes [3, 4]. However, poor rural communities of low-income and middle-income countries present a different nutritional epidemiological pattern characterized by chronic protein energy maternal and infant undernutrition [5]. Longstanding cohort studies in these types of communities have confirmed the association of maternal and child undernutrition with adult outcomes such as height, education level, income level, birth weight of offspring, BMI, glucose concentration, and blood pressure [6].

We lack knowledge of the association of adverse developmental conditions of subjects born in poor rural communities and the level of physical capability in adulthood. In economically developed countries, it has been found that prenatal and childhood growth are associated with the level of physical capability [7]. The hypothesis of the study was that adverse early developmental conditions accelerate the loss of physical capability in adulthood. Thus, the aim of the study was to assess the physical capability of members of a birth cohort of all children born in a poor rural community of Mexico in 1966-67 and its association with early developmental conditions.

\section{Methods}

\section{The initial study}

The study used data from the Tlaltizapán Birth Cohort, which consisted of all born -336 children- in the rural community of Tlaltizapán, in the State of Morelos, Mexico, between March $1^{\text {st }}, 1966$, and February $28^{\text {th }}$, 1967. The objective of that study was to investigate the impact of childhood malnutrition on growth and mental development [8]. All pregnant women in the community were identified, and data on the household physical and sanitary conditions, and the parents' height, weight, personal hygiene, formal education, income, and access to mass media were registered. At delivery, the health status and anthropometric measurements of the infant were obtained. The children's physical and mental development were followed for approximately 14 years [9-12].

\section{The present study}

At the time of the death of the principal investigator in 1998, [13] most of the research files were lost. Twenty years later, we were able to recover information that allowed us to trace the members of the birth cohort and investigate their status. We found that four members died in utero, 22 died in the $1^{\text {st }}$ year (death rate of $65.5 / 1000$ LB) and 6 died before five years (death rate of 17.8/1000 people). It was not possible to locate 133 of the subjects (39.6\%); from the remaining subjects, 10 (3.0\%) lived in other Mexican States, and 43 (12.8\%) lived in the USA.
We contacted 118 subjects (35.1\%) still living in the community; eighty-two of them (50 women and 32 men), aged 51-52 years, agreed to participate in the study and gave written informed consent to be clinically evaluated. We recovered original information on the household's sanitary level, family organization, size, and SES, the anthropometric data of both parents, and the mother's reproductive history. Data on infant birth weight was recovered in $21 \%$ of the cases, increments of weight, height, and head circumference in the first six months were recovered in $56.1 \%$ of the cases and weaning age was recovered in $46 \%$ of the cases.

The clinical evaluation took place at the National Institute of Geriatrics, Mexico City (INGER) between August 2018 and March 2019. The following parameters were evaluated: 1 . Anthropometric data: weight, height, arm, waist, and calf circumferences; 2. Body composition: a) Lean, bone and fat mass measured with dual X-ray absorptiometry [DEXA, ("HOLOGIC ${ }^{\circledR}$, Discovery QDR Series $\left.{ }^{\circledR}\right)$ ], [14] and b) muscular and fat mass with bioimpedance (seca MBCA 514n) [15]; 3. Geriatric syndromes using the a) Cognitive Scale (Mini mental state examination, MMSE ${ }^{\circledR}$ ), [16] b) Depression Scale, (CESD7), [17] c) Risk and Fear of Falls Scales, [18, 19] d) Drug Consumption Scale, [20] e) Fried Frailty Scale, [21] f) Barthel and Lawton Functionality and Daily Life Activities scale, [22, 23] and g) Champ's Physical Activity and Energy Consumption assessment; [24] 4. PC evaluation: a) Hand Grip Strength (HGS) (Handgrip Dynamometer ${ }^{\circledR}$ with duplicate measurements for each hand, with the subjects in a standing position with the elbow at an angle of 180 degrees, and highest measurement was taken as the final value), [25] b) Gait Speed (GS) (Walkway measuring equipment (Gaitrite ${ }^{\circledR}$ Mod. Platinum $20),[26]$ c) the 30-s Chair Stand Test $(\mathrm{ChS})\left(\right.$ Silverfit $\left.^{\circledR}\right)$, [27] and d) the Standing Balance- Eyes Opened Test (SB) comprised tandem, semitandem, side-by-side stands, and one-legged balance; [28] 5. Self-reported smoking status and alcohol intake, and chronic morbidities; [29] 6. History of heart attack, stroke, cancer, diabetes mellitus, and arterial hypertension; 7. Sitting and standing blood pressure, pulse and respiratory rates, and oxygen saturation were measured in duplicate and with standardized measurements; 8. Biochemical, chemical, and haematological measurements of 36 analytes performed with standardized automatic equipment; and 9. Diagnoses of obesity, osteoporosis, diabetes mellitus, dyslipidaemias, hypertension, and anaemia, with international criteria adapted to the Mexican population. All evaluations were made by standardized professional nurses with the subjects wearing light clothing.

All participants provided written informed consent for the study, genetic data and personal information security. 
Enrolment and consent procedures for this study were approved by the institutional review boards of the Bioethics and Research of the National Institute of Geriatrics and of the National Institute of Paediatrics under the number INP-INGER 06/2018. All methods employed in the study were performed in accordance with the relevant international guidelines and regulations, as well as those from the Ley General de Salud of Mexico.

\section{Statistical analysis}

We used multiple linear regression in R software (R 3.4.3, Vienna, Austria: R Foundation for Statistical Computing) [30]. The first step of model building aimed to identify the adult clinical variables significantly associated with HGS, GS, ChS scores, and SB scores. Since the SB scores showed low variability, they were eliminated from further analysis. In the second step of the analysis, to control for confounding factors, we built a model for each prenatal, birth and postnatal infant variable, adjusting for adult variables that proved to be significantly associated with the $\mathrm{PC}$ variables.

\section{Results}

Table 1 presents the descriptive statistics of the anthropometric, clinical, functional and pathological variables of the participants aged 51-52 years that showed statistical significance in the multivariable models.

Both men and women had near low median height, with low minimum values, and median BMI in the normal range. The median HGS of women was very low; the prevalence of diabetes mellitus and systemic arterial hypertension were high, and there was a deficit in the MMSE test.

Table 2 shows the descriptive statistics of the prenatal, birth, and postnatal variables of the participants, their parents, and family.

The described variables were those with a significant association with PC outcome variables in the multivariable models. At the participants' births, the families were

Table 1 Participants'somatometric, clinical, functional, and pathological characteristics measured at age $51-52$ by sex

\begin{tabular}{|c|c|c|c|c|c|c|c|c|}
\hline Variable & \multicolumn{4}{|c|}{ Women $(N=50)$} & \multicolumn{4}{|c|}{ Men $(N=32)$} \\
\hline Quantitative variables & Median & Min & & Max & Median & Min & & Max \\
\hline Adult height (m) & 1.54 & 1.40 & & 1.62 & 1.65 & 1.53 & & 1.82 \\
\hline Right Leg Length (cm) & 82.0 & 71.0 & & 87.6 & 84.6 & 73.0 & & 96.2 \\
\hline Knee height (cm) & 42.9 & 37.0 & & 50.5 & 46.8 & 40.3 & & 51.0 \\
\hline Foot width $(\mathrm{cm})$ & 9.0 & 8.0 & & 10.5 & 10.0 & 9.0 & & 11.0 \\
\hline Body Mass Index $\left(\mathrm{kg} / \mathrm{m}^{2}\right)$ & 29.8 & 20.8 & & 42.1 & 27.8 & 21.5 & & 39.6 \\
\hline Lean mass index (muscular kg/m²) & 15.55 & 12.30 & & 19.30 & 18.45 & 14.90 & & 22.70 \\
\hline Energy expenditure (kcal/day) & $2,055.3$ & $1,781.7$ & & $2,626.4$ & $2,938.60$ & $2,503.8$ & & $4,031.5$ \\
\hline Bioelectric impedance phase angle $\left(^{\circ}\right)$ & 5.3 & 3.4 & & 6.4 & 5.8 & 4.8 & & 6.6 \\
\hline Resting respiratory rate (breaths/minute) & 18 & 15 & & 24 & 20 & 14 & & 25 \\
\hline Resting Diastolic Blood Pressure (mmHg) & 70 & 50 & & 98 & 77 & 60 & & 96 \\
\hline Pulse pressure $(\mathrm{mmHg})$ & 40 & 25 & & 80 & 40 & 24 & & 68 \\
\hline Uric acid blood concentration (mg/dl) & 4.8 & 3.0 & & 8.2 & 6.2 & 4.1 & & 9.0 \\
\hline Depression Score & 5 & 0 & & 19 & 1 & 0 & & 12 \\
\hline Frailty index & 1 & 0 & & 4 & 1 & 1 & & 3 \\
\hline Grip strength (kg) & 22 & 12 & & 32 & 40 & 21 & & 52 \\
\hline Gait speed (cm/s) & 105.8 & 66.1 & & 157.9 & 107.7 & 79.3 & & 152.9 \\
\hline Chair stand test (stands/30 s) & 16 & 12 & & 21 & 17 & 12 & & 26 \\
\hline Bipodal balance (s) & 10 & 10 & & 10 & 10 & 10 & & 10 \\
\hline Semitandem balance (s) & 10 & 10 & & 10 & 10 & 10 & & 10 \\
\hline Tandem balance & 10 & 7 & & 10 & 10 & 10 & & 10 \\
\hline \multirow[t]{2}{*}{ One-legged balance } & 10 & 0 & & 10 & 10 & 9 & & 10 \\
\hline & \multicolumn{4}{|l|}{ Women } & \multicolumn{4}{|l|}{ Men } \\
\hline Dichotomous variables & \multicolumn{2}{|l|}{$\mathrm{n}$} & \multicolumn{2}{|l|}{$\%$} & \multicolumn{2}{|l|}{ n } & \multicolumn{2}{|l|}{$\%$} \\
\hline Type 2 diabetes mellitus & \multicolumn{2}{|l|}{10} & \multicolumn{2}{|l|}{$20 \%$} & \multicolumn{2}{|l|}{5} & \multicolumn{2}{|l|}{$16 \%$} \\
\hline Systemic arterial hypertension & \multicolumn{2}{|l|}{11} & \multicolumn{2}{|l|}{$22 \%$} & \multicolumn{2}{|l|}{7} & \multicolumn{2}{|l|}{$22 \%$} \\
\hline $\begin{array}{l}\text { Mini-Mental State Examination (deficit defined } \\
\text { by Folstein criterion) }\end{array}$ & \multicolumn{2}{|l|}{5} & \multicolumn{2}{|l|}{$10 \%$} & \multicolumn{2}{|l|}{4} & \multicolumn{2}{|l|}{$13 \%$} \\
\hline
\end{tabular}


Table 2 Characteristics of the prenatal, birth and postnatal variables of the participants, their parents, and their family

\begin{tabular}{|c|c|c|c|c|c|c|c|c|c|}
\hline \multirow[t]{2}{*}{ Quantitative variables } & & \multicolumn{4}{|c|}{ Women } & \multicolumn{4}{|c|}{ Men } \\
\hline & & $\mathbf{N}$ & Median & Min & Max & $\mathbf{N}$ & Median & Min & Max \\
\hline \multicolumn{2}{|l|}{ Participant's Z score of weight for age at birth } & 17 & -0.68 & -2.25 & 1.26 & 12 & -0.69 & -1.32 & 1.15 \\
\hline \multicolumn{2}{|l|}{ Participant's Z score of head circumference at birth } & 4 & -0.53 & -0.75 & -0.32 & 6 & 0.42 & -1.15 & 1.21 \\
\hline \multicolumn{2}{|l|}{ Participant's increase in arm circumference from the 3rd to 4th month (cm) } & 46 & 0.6 & -1.3 & 2.0 & 29 & 0.5 & -0.9 & 2.0 \\
\hline \multicolumn{2}{|l|}{ Participant's weaning age (months) } & 38 & 16.5 & 2 & 28 & 23 & 15 & 1 & 23 \\
\hline \multicolumn{2}{|l|}{ Postpartum maternal BMI $\left(\mathrm{kg} / \mathrm{m}^{2}\right)$} & 48 & 23.1 & 18.0 & 31.1 & 32 & 23.9 & 19.4 & 36.6 \\
\hline \multicolumn{2}{|l|}{ Father's BMI $\left(\mathrm{kg} / \mathrm{m}^{2}\right)$} & 45 & 21.9 & 18.7 & 31.7 & 31 & 21.8 & 14.7 & 29.5 \\
\hline \multicolumn{2}{|l|}{ Father's formal education (years) } & 46 & 2 & 0 & 16 & 31 & 2 & 0 & 11 \\
\hline \multicolumn{2}{|l|}{ Number of family members at birth } & 47 & 7 & 3 & 13 & 32 & 5 & 3 & 13 \\
\hline \multicolumn{2}{|l|}{ Family SES (The higher the value, the lower the status) } & 45 & 14 & 5 & 19 & 28 & 13 & 7 & 20 \\
\hline \multirow{2}{*}{\multicolumn{2}{|c|}{ Ordinal/Dichotomous variables }} & \multicolumn{4}{|c|}{ Women } & \multicolumn{4}{|c|}{ Men } \\
\hline & & $\mathrm{n}$ & $\%$ & & & $\mathrm{n}$ & $\%$ & & \\
\hline \multirow[t]{3}{*}{ Participant's Z score of weight increase from birth to 6 months } & $<-1$ & 19 & $41.3 \%$ & & & 10 & $34.5 \%$ & & \\
\hline & -1 to +1 & 20 & $43.5 \%$ & & & 15 & $51.7 \%$ & & \\
\hline & $>+1$ & 7 & $15.2 \%$ & & & 4 & $13.8 \%$ & & \\
\hline \multirow[t]{3}{*}{ Participant's Z score of head circumference increase from birth to 6 months } & $<-2$ & 6 & $13.0 \%$ & & & 3 & $10.3 \%$ & & \\
\hline & -2 to +1 & 37 & $80.4 \%$ & & & 16 & $55.2 \%$ & & \\
\hline & $>+1$ & 3 & $6.5 \%$ & & & 10 & $34.5 \%$ & & \\
\hline \multirow[t]{3}{*}{ Mother's height Z score } & $<-1.5$ & 39 & $81.3 \%$ & & & 26 & $81.3 \%$ & & \\
\hline & -1.5 to 0 & 9 & $18.7 \%$ & & & 5 & $15.6 \%$ & & \\
\hline & $>0$ & 0 & $0 \%$ & & & 1 & $3.1 \%$ & & \\
\hline \multirow[t]{3}{*}{ Mother's postpartum BMI } & $<19 \mathrm{~kg} / \mathrm{m} 2$ & 1 & $2.1 \%$ & & & 0 & $0 \%$ & & \\
\hline & 19 to $<25 \mathrm{~kg} / \mathrm{m}^{2}$ & 35 & $72.9 \%$ & & & 20 & $62.5 \%$ & & \\
\hline & $\geq 25 \mathrm{~kg} / \mathrm{m}^{2}$ & 12 & $25.0 \%$ & & & 12 & $37.5 \%$ & & \\
\hline \multirow[t]{3}{*}{ Father's BMI } & $<19 \mathrm{~kg} / \mathrm{m}^{2}$ & 1 & $2 \%$ & & & 2 & $6 \%$ & & \\
\hline & 19 to $<25 \mathrm{~kg} / \mathrm{m}^{2}$ & 36 & $80 \%$ & & & 25 & $81 \%$ & & \\
\hline & $\geq 25 \mathrm{~kg} / \mathrm{m}^{2}$ & 8 & $18 \%$ & & & 4 & $16 \%$ & & \\
\hline \multirow[t]{3}{*}{ Family's SES } & High & 10 & $22.2 \%$ & & & 6 & $21.4 \%$ & & \\
\hline & Middle & 21 & $46.7 \%$ & & & 15 & $53.6 \%$ & & \\
\hline & Low & 14 & $31.1 \%$ & & & 7 & $25.0 \%$ & & \\
\hline \multirow[t]{2}{*}{ Family type } & Nuclear & 41 & $85.4 \%$ & & & 23 & $90.6 \%$ & & \\
\hline & Extended & 7 & $14.6 \%$ & & & 9 & $9.4 \%$ & & \\
\hline
\end{tabular}

large, with a low to middle SES, and a father with a low level of formal education. The median paternal BMI fell within the normal range; based on a postpartum weight measurement, the median maternal BMI presented a distribution from a low (18.0) to a relatively high value (31.1), with a median within the normal range. The categorical mothers' height distribution showed that they were of short stature compared to the international standard. The median $\mathrm{Z}$ score values of birth weight, head circumference, and the increments during the first six months of life showed distributions skewed to low values relative to the international standards $[31,32]$.

Table 3 presents the HGS, GS and ChS predictors of adult age in the multivariable model.

Related to HGS, male sex, height, lean mass, and phase angle (bioimpedance indicator of muscular mass) had significant positive effects, while energy expenditure and pulse pressure had negative effects; the depression score showed a trend towards significance with a negative effect. Regarding GS, foot width, resting respiratory rate, diastolic blood pressure, uric acid blood concentration, and the diagnosis of diabetes mellitus showed a positive association. Variables negatively associated with GS were male sex, BMI, leg length, knee height, the diagnosis of hypertension and poor performance on the MMSE. With the ChS test, male sex was the only variable that was positively associated, while height and the frailty index variables were negatively associated.

Table 4 shows the prenatal, birth and postnatal variables with significant effects on HGS, GS, and ChS scores, each of which was adjusted by the adult predictors described in Table 3.

The higher the body size at birth (birth weight, birth head circumference), family SES, parental nutrition (maternal and paternal BMI), and family size, the higher the adult maximal HGS. Infant growth measurements in 
Table 3 Hand grip strength (HGS), gait speed (GS) and chair stand test (ChS) adulthood predictors

\begin{tabular}{|c|c|c|c|c|c|}
\hline Dependent & Predictor & Coefficient $(95 \% \mathrm{Cl})$ & $P$ & Adjustedr2 & Globalp-value \\
\hline \multirow[t]{8}{*}{ HGS (kg) } & (Intercept) & $-93.06(-116.5$ to -69.6$)$ & $<0.001$ & 0.8794 & $<0.001$ \\
\hline & Sex (Female 1, Male 2) & $7.93(4.64$ to 11.21$)$ & $<0.001$ & & \\
\hline & Adult height $(\mathrm{m})$ & 64.33 (49.69 to 78.96$)$ & $<0.001$ & & \\
\hline & Lean mass index (muscular kg/m²) & 0.83 (0.26 to 1.39$)$ & 0.0046 & & \\
\hline & Energy expenditure (kcal/day) & $-0.01(-0.01$ to -0.001$)$ & 0.0092 & & \\
\hline & Bioelectric impedance phase angle $\left(^{\circ}\right)$ & 2.13 (0.54 to 3.72 ) & 0.0094 & & \\
\hline & Pulse pressure $(\mathrm{mmHg})$ & $-0.1(-0.18$ to -0.02$)$ & 0.0207 & & \\
\hline & Depression Score & $-0.15(-0.3$ to $<0.0001)$ & 0.0501 & & \\
\hline \multirow[t]{13}{*}{$\mathrm{GS}(\mathrm{cm} / \mathrm{s})$} & (Intercept) & 212.7 (127.29 to 298.12$)$ & $<0.001$ & 0.462 & $<0.0001$ \\
\hline & Sex (Female 1, Male 2) & $-22.05(-35.51$ to -8.58$)$ & 0.002 & & \\
\hline & Body Mass Index $\left(\mathrm{kg} / \mathrm{m}^{2}\right)$ & $-2.08(-2.91$ to -1.26$)$ & $<0.001$ & & \\
\hline & Grip strength $(\mathrm{kg})$ & 1.32 (0.69 to 1.96$)$ & $<0.001$ & & \\
\hline & Right Leg Length (cm) & $-1.78(-2.76$ to -0.79$)$ & $<0.001$ & & \\
\hline & Knee height $(\mathrm{cm})$ & $-1.56(-2.89$ to -0.24$)$ & 0.021 & & \\
\hline & Foot width $(\mathrm{cm})$ & 7.17 (0.9 to 13.43$)$ & 0.026 & & \\
\hline & Resting respiratory rate (breaths/minute) & $1.78(0.47$ to 3.08$)$ & 0.008 & & \\
\hline & Resting Diastolic Blood Pressure (mmHg) & 0.56 (0.17 to 0.96$)$ & 0.006 & & \\
\hline & Uric acid blood concentration (mg/dl) & 4.31 (1.79 to 6.82$)$ & 0.001 & & \\
\hline & Type 2 Diabetes mellitus (with diagnosis $=1$ ) & 11.1 (2.48 to 19.71$)$ & 0.012 & & \\
\hline & Systemic Arterial Hypertension (with diagnosis $=1$ ) & $-9.85(-18.26$ to -1.44$)$ & 0.022 & & \\
\hline & Mini-Mental State Examination (Normal=0, Deficit $=1$ ) & $-11.19(-21.19$ to -1.19$)$ & 0.029 & & \\
\hline \multirow[t]{4}{*}{ ChS (stands/30 s) } & (Intercept) & 38.56 (22.74 to 54.38$)$ & $<0.0001$ & 0.1342 & 0.0027 \\
\hline & Sex (Female 1, Male 2) & 3.18 (1.39 to 4.96) & 0.0007 & & \\
\hline & Adult height $(\mathrm{m})$ & $-15.82(-26.59$ to -5.05$)$ & 0.0045 & & \\
\hline & Frailty index & $\begin{array}{l}-1.14 \\
(-2.02 \text { to }-0.26)\end{array}$ & 0.0111 & & \\
\hline
\end{tabular}

the first six months were negatively associated with HGS: higher increment values of weight and head circumference, standardized for age and sex, were negatively associated with HGS; increases in arm circumference from the $3^{\text {rd }}$ to $4^{\text {th }}$ months of age also had a negative effect. Performance on the GS test was negatively affected by maternal size (high and low BMI, and low and abovemedian height), low family SES, living in a nuclear family at birth and both slow and accelerated head circumference growth. Having been weaned later and having a father with more formal education were variables that were associated with better performance on the test. For the ChS test, having a long weaning period was the only variable found to be significantly and negatively associated.

\section{Discussion}

The specificity and strength of the associations of the PC tests with early influences found in the present study can be derived from the set of adjustment variables associated with each of them, i.e., for HGS, the main predictive variables were adjusted by sex, height, and muscular mass; for GS, they included sex and body shape variables, such as leg length, foot width, and BMI; and in the ChS model, the only variables were sex, height and the frailty index. These differences in adjustment variables by test indicate the different physiological parameters required to adjust in modelling the environmental and developmental associations.

Our results confirm the association of prenatal and birth factors with midlife PC in adults. These results are consistent with the hypothesis of the developmental origins of adult health and disease [2,33,34]. The negative association of HGS with weight and head circumference increments during the first six months of life that was found provides new insight into early life adverse influences on adult PC in a group of underprivileged subjects with a rural background. In the case of populations of European ancestry, the Northern Finland Birth Cohort Study, an investigation on growth during the first year of life, reported that greater infant weight gain was associated with lower muscle endurance and poorer aerobic fitness in adulthood, although these effects could have been mediated by adult body size [35]. In our case, the 


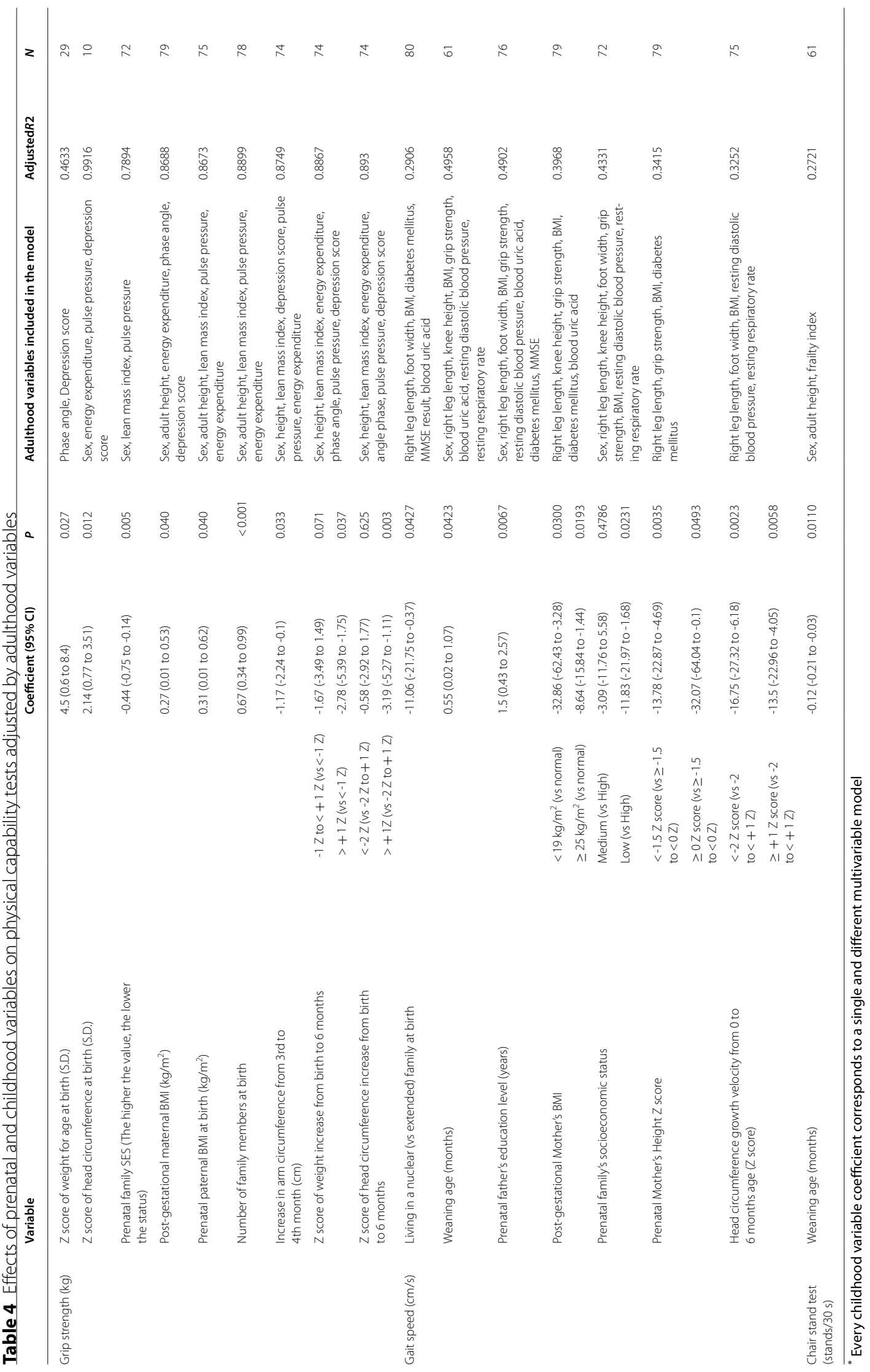


adjustment variables included height and muscle mass. Other studies in economically developed populations have shown that unfavourable influences such as low SES, maternal education and income experienced during prenatal and childhood periods were associated with weaker HGS, low muscular strength, or worst PC in adulthood $[33,36-40]$. There are also reports of positive effects of birth weight on muscle strength both in association with or independent of body size [41-43].

In our study, the associations of environmental, prenatal, birth and postnatal factors with midlife PC tests were positive or negative. For instance, better midlife HGS performance was positively associated with family SES and size, maternal and paternal nutritional status, and birth weight. These results suggest that the prenatal improvement of these parameters could result in better future ageing trajectories and adult PC performance. On the negative side of the spectrum, postnatal growth velocity indicators showed a negative association with HGS, a result that is consistent with the high incidence of postnatal malnutrition due to diarrhoeal diseases and the late introduction of foods that are different from the mother's milk, a pattern commonly found in Tlaltizapán $[11,12]$. In the same way, in a Finnish cohort study, BMI increases from ages 2 to 11 years in males (but not in females) was positively associated with frailty at 67-79 years of age [44]. In contrast, in a British cohort, height increases, from ages 2 to 7 years, was also related to HGS but with a positive effect [42]. Regarding GS, better performance was associated with higher levels of the father's formal education, which is an SES indicator. This result is consistent with a Chinese study that reported that an illiterate paternal education level (vs. literate) in early life was associated with an increased risk of frailty at $\geq 60$ years of age [45]. Infant feeding habits have been associated with the development of malnutrition in rural populations. In the present study, better GS performance was associated with late weaning, a probable nutritional protective factor in a poor rural environment; the median weaning age of the participants was 15 and 16 months for men and women, respectively, with a range of 1 to 28 months. Sanjur, Cravioto, and coworkers reported the practice of prolonged breastfeeding among the cohort's mothers $[46,47]$. Similarly, the early introduction of foods that were different from breast milk was a risk factor for marasmus because of the deficit of highquality protein and energy. As was the case for HGS, postnatal growth velocity indicators were negatively associated with GS performance, confirming the influence of postnatal malnutrition on midlife PC. In addition, lower GS performance was associated with social factors such as family type and SES. To interpret these findings, it can be speculated that poor nuclear rural families lack sufficient support from other family members. This hypothesis is consistent with other studies where low SES in childhood or before the age of 16 was associated with low GS in adulthood [37, 48]. Indicators of maternal nutritional level (post-gestational BMI and height) were negatively associated with GS performance. Height is considered a cumulative index of nutrition, [49] and the cohort's mothers were of short stature; Cravioto et al. reported that the median height of the cohort's mothers was $147.5 \mathrm{~cm}$, and the first quartile was only $145.5 \mathrm{~cm}$ [8], a short stature compared with international standards. The multivariable model for the $\mathrm{ChS}$ test showed only a weak negative association with weaning age, a result that contrasts with studies that reported the influence of social variables such as the father's occupational class and low SES on ChS performance $[33,50]$.

Overall, our results indicate the negative influence of a poor rural family environment, a low nutritional status of parents, especially of the mother, and low intrauterine and postnatal growth, the latter associated with inadequate infant feeding practices, on midlife PC. At the time of the cohort's inception, the relatively small Mexican rural community of Tlatizapán had a low standard of living, as documented by Cravioto et al. in the Monograph [8]. The health and nutrition surveys at that time revealed that extended families lived in households with poor sanitary conditions and consumed a monotonous diet limited in energy and high-quality protein. Thus, early deficient nutritional status is most likely a contributing factor to the low average HGS of the participants, compared with the average of adults of the same age of economically developed countries and even of residents of Mexico City, as shown in Table 5 [25, 51-53]. This observation is consistent with the report by Dodds et al. [54], who showed that normative HGS data from developing regions were lower than those of developed regions of the world.

Muscular strength, an important component of PC, particularly HGS, is a function of muscle mass development during the foetal stage. In a Finnish study of elderly frail women, postpartum maternal BMI was related to muscle strength in specific (but not in most) muscle groups: the daughters of obese mothers were weaker than the daughters of lean mothers [57]. On the other side of the nutritional spectrum, it has been demonstrated that maternal undernutrition limits the proliferation of precursor muscular cells and reduces the number of fibres formed, a process thought to be mediated by epigenetic changes that could explain, among other factors, the lasting effects on midlife PC $[56,58]$. At the time the original research was implemented in Tlaltizapán, nearly $70 \%$ of the Mexican population lived in rural communities of similar conditions, 
Table 5 Handgrip strength by sex in our study and four community studies with a similar age group

\begin{tabular}{|c|c|c|c|c|c|c|}
\hline Sex & Source & Age range & $N$ & Mean & $95 \% \mathrm{Cl}$ & Significance* \\
\hline \multirow[t]{5}{*}{ Females } & Current study & $51--52$ & 50 & 22.2 & $20.9-23.5$ & Lowest \\
\hline & Mexico City [28] & $50-59$ & 75 & 25.0 & $24.1-25.9$ & 2nd Lowest \\
\hline & Korea [54] & $50-54$ & 535 & 26.9 & $26.5-27.3$ & \\
\hline & USA [55] & $50-59$ & 780 & 27.5 & $27.1-27.9$ & \\
\hline & UK [56] & $51-55$ & 4250 & 27.5 & $27.3-27.7$ & \\
\hline \multirow[t]{5}{*}{ Males } & Current study & $51--52$ & 32 & 38.5 & $36.1-40.9$ & Lowest \\
\hline & Mexico City [28] & $50-59$ & 74 & 42.0 & $40.9-43.1$ & \\
\hline & Korea [54] & $50-54$ & 386 & 43.3 & $42.7-43.9$ & \\
\hline & USA [55] & $50-59$ & 721 & 42.1 & $41.5-42.7$ & \\
\hline & UK [56] & $51-55$ & 3743 & 46.2 & $45.9-46.5$ & Highest \\
\hline
\end{tabular}

* Significant difference if $95 \% \mathrm{Cl}$ of one group does not imbricate with $95 \% \mathrm{Cl}$ of another

which favoured the incidence and prevalence of malnutrition. The extensive rural-urban migration that has taken place in Mexico in recent decades has reversed that proportion. The present urban population faces a high prevalence of obesity, diabetes, and hypertension. Demographic transitions in low-income countries has been characterized by four intergenerational cycles [57]. In our study, we documented low nutritional status in at least three generations: the cohort's grandmothers (data not shown), and stunted mothers giving birth to undernourished children who, in midlife, suffer from chronic conditions such as obesity, diabetes and hypertension.

The loss of information from the original study and the reduced sample size, partially due to refusal of the clinical evaluation, are the main limitations of the study. However, our study, although on a limited scale, contributes to the understanding of the present health problems and future ageing trajectories that populations, such as the Mexican population, are likely to face in the future.

\section{Conclusions}

The midlife physical capability of adults born in a rural community with low environmental and socioeconomic conditions is associated with low parental nutritional status, intrauterine and postnatal growth retardation and late weaning. Physical capability in adulthood is an indicator of pathological ageing trajectories. Our results stress the importance of promoting health conditions during development as a means to prevent future pathological ageing trajectories.

\section{Abbreviations}

PC: Physical capability; LB: Live births; SES: Socioeconomic status; HGS: Hand grip strength; GS: Gait speed; ChS: Chair stand test; SB: Standing balance; BMI: Body mass index.

\section{Acknowledgements}

Flavia Mendoza, Ángeles Galicia, María Luisa Ontiveros, Gladys Pérez, Brenda Ortíz, Carlos Ramos.

In memoriam

Joaquín Cravioto, José Luis Arredondo.

\section{Authors' contributions}

PA, conception, design, coordination, acquisition of data, and drafted the manuscript.MEA, design, statistical analysis, interpretation of data, and drafting the manuscript. VMM, acquisition and interpretation of data. JCGV, design, and molecular genetic studies. LPR, design of the informatic platform and data acquisition.CCT, curation and acquisition of data.CSP, clinical laboratory analysis. LMGR, design, and final approval of the manuscript. All Authors have read and approved the manuscript.

\section{Funding}

This Project was supported by the Consejo Nacional de Ciencia y Tecnología (CONACyT), Mexico, Grant CONACYT-FOSISS 2017 number 290287 under the name: "Condiciones sociales y de salud al Nacimiento, primera infancia y su relación con las condiciones en la edad adulta y la expresión genómica, como predictores de envejecimiento saludable desde los 50 años de edad". The publication of this paper was supported by a grant from the Secretaría de Educación, Ciencia, Tecnología e Innovación de la Ciudad de México CM-SECTEl/200/2020"Red Colaborativa de Investigación Traslacional para el Envejecimiento Saludable de la Ciudad de México (RECITES).

\section{Availability of data and materials}

The data sets generated and/or analyzed during the current study are not publicly available due to patient privacy, but are available from the corresponding author on reasonable request.

\section{Declarations}

\section{Ethics approval and consent to participate}

All participants provided written informed consent about the study, the genetic data and personal information security. Enrollment and consent procedures for this study were approved by the institutional review boards of Bioethics and Research of INGER, and Bioethics and Research Board of the National Institute of Pediatrics (INP), under the number of INP-INGER 06/2018. All methods employed in the study were performed in accordance with the relevant international guidelines and regulations, as well as those from the Ley General de Salud of Mexico.

\section{Consent for publication}

Not relevant.

Competing interests

The authors declare that they have not competing interests. 


\section{Author details}

${ }^{1}$ Department of Clinical Epidemiology, Direction of Research, Instituto Nacional de Geriatría, Blvd. Adolfo Ruiz Cortines No. 2767, Col. San Jerónimo Lídice, Alcaldía La Magdalena Contreras. Distrito Federal, CP. 10200 Ciudad de México, México. ${ }^{2}$ Research Unit of Epidemiology, Direction of Research, Instituto Nacional de Pediatría, Insurgentes Sur 3700, Letra C, Alcaldía Coyoacán, C.P. 04530 Ciudad de México, México. ${ }^{3}$ Research Unit of Epidemiology, Instituto Nacional de Pediatría, Insurgentes Sur 3700, Letra C, Alcaldía Coyoacán, C.P. 04530 Ciudad de México, México. ${ }^{4}$ Dirección de Investigación, Instituto Nacional de Geriatría, Col. San Jerónimo Lídice, Alcaldía La Magdalena Contreras. Distrito Federal, Blvd. Adolfo Ruiz Cortines No. 2767, CP. 10200, Ciudad de México, México. ${ }^{5}$ Department of Biomedical Engineering and Gerontechnology. Direction of Research, Instituto Nacional de Geriatría, Blvd. Adolfo Ruiz Cortines No. 2767, Col. San Jerónimo Lídice, Alcaldía La Magdalena Contreras. Distrito Federal, CP. 10200 Ciudad de México, México. ${ }^{6}$ Clinical Laboratory, Instituto Nacional de Pediatría. Laboratory of Clinical Chemistry, Insurgentes Sur 3700, Letra C, Alcaldía Coyoacán, C.P. 04530 Ciudad de México, México. ${ }^{7}$ Instituto Nacional de Geriatría, Blvd. Adolfo Ruiz Cortines No. 2767, Col. San Jerónimo Lídice, Alcaldía La Magdalena Contreras. Distrito Federal, CP. 10200 Ciudad de México, México.

Received: 21 July 2021 Accepted: 20 January 2022

Published online: 10 February 2022

\section{References}

1. Tarry-Adkins JL, Ozanne SE. Nutrition in early life and age-associated diseases. Ageing Res Rev. 2017;39:96-105.

2. Erikson JG. Developmental origins of health and disease -from a small body size at birth to epigenetics. Ann Med. 2016;48:456-67.

3. Vaiserman A, Lushchak O. Prenatal famine exposure and adult health outcomes: an epigenetic link. Environ Epigenet. 2021;7:1-5.

4. Lumey LH, Stein AD, Susser E. Prenatal famine and adult health. Annu Rev Public Health. 2011;32:237-62

5. Scrimshaw NS, Taylor CE, Gordon JE. Interactions of nutrition and infection. Geneva: Monogr Ser World Health Organ. 1968;57:3-329.

6. Victora CG, Adair L, Fall C, Hallal PC, Martorell R, Richter L, et al. Maternal and child undernutrition: consequences for adult health and human capital. Lancet. 2008;371:340-57.

7. Eriksson JG, Osmond C, Perälä M, et al. Prenatal and childhood growth and physical performance in old age-findings from the Helsinki Birth Cohort Study 1934-1944. Age (Dordr). 2015;37:108.

8. Cravioto J, Birch HG, de Licardie E, et al. The ecology of growth and development in a Mexican preindustrial community. Report 1: Method and findings from birth to one month of age. Monogr Soc Res Child Dev. 1969;34:1-76.

9. Cravioto J, de Licardie E. The long-term consequences of malnutrition. Nutr Rev. 1971;29:107-11.

10. Cravioto J, de Licardie E. The relation of size at birth and preschool clinical severe malnutrition. Acta Paediat. 1974:63:577-86.

11. Condon-Paoloni D, Cravioto J, Johnston FE, et al. Morbidity and Growth of Infants and Young Children in a Rural Mexican Village. Am J Public Health. 1977;67:651-6.

12. Scholl TO, Johnston FE, Cravioto J, et al. The relationship of growth failure (chronic undernutrition) to the prevalence of clinically severe protein-energy malnutrition and to growth retardation in protein-energy malnutrition. Am J Clin Nutr. 1972;32:872-8.

13. Arroyo P, Mandujano M. Joaquín Cravioto (1922-1998). J Nutr. 2000;130:2867-9.

14. Shepherd JA, Ng B, Sommer M, et al. Body composition by DEXA. Bone. 2017;104:101-5.

15. Alvero-Cruz JR, Correas Gómez L, Ronconi M, et al. La bioimpedancia eléctrica como método de estimación de la composición corporal: normas prácticas de utilización [Electrical bioimpedance as a method for estimating body composition: practical rules for use]. Rev Andal Med Deporte. 2011;4:167-74

16. Marshal F, Folstein MF, Folstein SE, et al. "Mini-Mental State". A practical method for grading the cognitive state of patients for the clinician. $J$ Psychiat Res. 1975;12:189-98.
17. Salinas-Rodríguez A, Manrique-Espinoza B, Acosta-Castillo I, et al. Validation of a cutoff for the Depression Scale of the Center for Epidemiologic Studies, Brief Version (CESD-7). Salud Publica Mex. 2013;55:267-74.

18. Stevens JA, Phelan EA. Development of STEADI: A Fall Prevention resource for health care providers. Health Promot Pract. 2013;14:706-14.

19. Yardley L, Beyer N, Hauer K, et al. Development and initial validation of the Falls Efficacy Scale-International (FES-I). Age Ageing. 2005;34:614-9.

20. Cho S, Lau SJ, Tandon V, et al. Geriatric drug evaluation: where are we now and where should we be in the future? Arch Int Med. 2011;171:937-40

21. Fried LP, Tangen CM, Walston J, et al. Frailty in older adults: evidence for a phenotype. J Gerontol Med Sci. 2001;56A:M146-56.

22. Cid-Ruzafa J, Damián-Moreno J. Valoración de la discapacidad física: el Índice de Barthel [Disability evaluation: Barthel's index]. Rev Esp Salud Publica. 1997;71:127-37.

23. Lawton MP, Brody EM. Assessment of older people: self-maintaining and instrumental activities of daily living. Gerontologist. 1969;9:179-86.

24. Stewart AL, Mills KM, King AC, et al. CHAMPS physical activity questionnaire for older adults: outcomes for interventions. Med Sci Sports Exerc. 2001;33:1126-41.

25. Rodríguez-García WD, García-Castañeda L, Orea-Tejeda A, et al. Handgrip strength: Reference values and its relationship with bioimpedance and anthropometric variables. Clin Nutr ESPEN. 2017;19:54-8.

26. Bohannon RW, Andrews AW, Thomas MW. Walking speed: reference values and correlates for older adults. J Orthop Sports Phys Ther. 1996;24:86-90.

27. Jones CJ, Rikli RE, Beam WC. A 30-s chair-stand test as a measure of lower body strength in community-residing older adults. Res Q Exerc Sport. 1999;70:113-9.

28. Guralnik JM, Simonsick EM, Ferrucci L, et al. A short physical performance battery assessing lower extremity function: association with self-reported disability and prediction of mortality and nursing home admission. J Gerontol Med Sci. 1994;49:M85-94.

29. Charlson ME, Pompei P, Ales KL, et al. A new method of classifying prognostic comorbidity in longitudinal studies: development and validation. J Chron Dis. 1987:40:373-83.

30. R Core Team. R: A language and environment for statistical computing. Vienna: R Foundation for Statistical Computing; 2018. (https://www.Rproject.org/).

31. World Health Organization. Child growth standards; Head circumference velocity, Length velocity, Weight velocity; 6-month increments. Geneva: World Health Organization; 2009. (https://www.who.int/tools/childgrowth-standards/who-multicentre-growth-reference-study Accessed May 2021).

32. National Center for Health Statistics. Stature-for-age charts, 2 to 20 years, selected stature z-scores in centimeters, by sex and age. Atlanta: Centers for Disease Control and Prevention; 2009. (https://www.cdc.gov/growt hcharts/zscore.htm. Accessed May 2021).

33. Birnie K, Cooper R, Martin RM, et al. Childhood socioeconomic position and objectively measured physical capability levels in adulthood: A systematic review and meta-analysis. PLoS ONE. 2011. https://doi.org/10. 1371/journal.pone.0015564.

34. Kuh D, Hardy R, Blodgett JM, et al. Developmental factors associated with decline in grip strength from midlife to old age: a British birth cohort study. BMJ Open. 2019. https://doi.org/10.1136/bmjopen-2018-025755.

35. Ridgway CL, Ong KK, Tammelin T, et al. Birth size, infant weight gain, and motor development influence adult physical performance. Med Sci Sports Exerc. 2009;41:1212-21.

36. Carney C, Benzeval M. Social patterning in grip strength and in its association with age; a cross sectional analysis using the UK Household Longitudinal Study (UKHLS). BMC Public Health. 2018. https://doi.org/10. 1186/s12889-018-5316-x.

37. Cheval B, Boisgontier MP, Orsholits D, et al. Association of early- and adultlife socioeconomic circumstances with muscle strength in older age. Age Ageing. 2018;47:398-407.

38. Vable AM, Gilsanz P, Kawachi I. Is it possible to overcome the "long arm" of childhood socioeconomic disadvantage through upward socioeconomic mobility? J Public Health (Oxf). 2019;41:566-74.

39. Caleyachetty R, Hardy R, Cooper R, et al. Modeling exposure to multiple childhood social risk factors and physical capability and common affective symptoms in later life. J Aging Health. 2018;30:386-407. 
40. Kuh D, Bassey J, Hardy R, et al. Birth weight, childhood size, and muscle strength in adult life: evidence from a birth cohort study. Am J Epidemiol. 2002;156:627-33.

41. Dodds R, Denison HJ, Ntani G, et al. Birth weight and muscle strength: a systematic review and meta-analysis. J Nutr Health Aging. 2012;16:609-15.

42. Kuh D, Hardy R, Butterworth $S$, et al. Developmental origins of midlife grip strength: findings from a birth cohort study. J Gerontol A Biol Sci Med Sci. 2006;61:702-6.

43. Ahlqvist $\mathrm{VH}$, Persson $\mathrm{M}$, Ortega FB, et al. Birth weight and grip strength in young Swedish males: a longitudinal matched sibling analysis and across all body mass index ranges. Sci Rep. 2019. https://doi.org/10.1038/ s41598-019-46200-0.

44. Haapanen MJ, Perälä MM, Osmond C, et al. Infant and childhood growth and frailty in old age: the Helsinki Birth Cohort Study. Aging Clin Exp Res. 2019;31:717-21.

45. Li Y, Xue QL, Odden MC, et al. Linking early life risk factors to frailty in old age: evidence from the China Health and Retirement Longitudinal Study. Age Ageing. 2020;49:208-17.

46. Sanjur DM, Cravioto J, Rosales L, et al. Infant feeding and weaning practices in a rural preindustrial setting. A sociocultural approach Acta Paediat. 1970;59:3-45

47. Sanjur D, Cravioto J, Van Veen A. Infant nutrition and sociocultural influences in a village in Central Mexico. Trop Geogr Med. 1970;22:443-51.

48. Birnie K, Martin RM, Gallacher J, et al. Socioeconomic disadvantage from childhood to adulthood and locomotor function in old age: a lifecourse analysis of the Boyd Orr and Caerphilly prospective studies. J Epidemiol Community Health. 2011;65:1014-23.

49. Perkins JM, Subramanian SV, Smith GD, et al. Adult height, nutrition, and population health. Nutr Rev. 2016;74:149-65.

50. Strand BH, Cooper R, Hardy R, et al. Lifelong socioeconomic position and physical performance in midlife: results from the British 1946 birth cohort. Eur J Epidemiol. 2011;26:475-83.

51. Kim M, Won CW, Kim M. Muscular grip strength normative values for a Korean population from the Korea National Health and Nutrition Examination Survey, 2014-2015. PLoS ONE. 2018. https://doi.org/10.1371/journ al.pone.0201275.

52. Bohannon RW, Wang YC, Yen SC, et al. Handgrip strength: A comparison of values obtained from the NHANES and $\mathrm{NIH}$ toolbox studies. Am J Occup Ther. 2019. https://doi.org/10.5014/ajot.2019.029538.

53. Dodds RM, Syddall HE, Cooper R, et al. Grip strength across the life course: Normative data from twelve British studies. PLoS ONE. 2014. https://doi. org/10.1371/journal.pone.0113637.

54. Dodds RM, Syddall HE, Cooper R, et al. Global variation in grip strength: a systematic review and meta-analysis of normative data. Age Ageing. 2016:45:209-16

55. Wasenius NS, Simonen M, Penttinen $L$, et al. Effect of maternal weight during pregnancy on offspring muscle strength response to resistance training in late adulthood. Adv Med Sci. 2018;63:353-8.

56. Yan X, Zhu M, Dodson MV, et al. Developmental programming of fetal skeletal muscle and adipose tissue development. J Genomics. 2013;1:29-38.

57. Gluckman PD, Hanson MA, Buklijas T. A conceptual framework for developmental origins of health and disease. J Dev Orig Health Dis. 2010;1:6-18.

58. Hsu Ch, Tain Y. The good, the bad, and the ugly of pregnancy nutrients and developmental programming of adult disease. Nutrients. 2019. https://doi.org/10.3390/nu11040894.

\section{Publisher's Note}

Springer Nature remains neutral with regard to jurisdictional claims in published maps and institutional affiliations.

Ready to submit your research? Choose BMC and benefit from:

- fast, convenient online submission

- thorough peer review by experienced researchers in your field

- rapid publication on acceptance

- support for research data, including large and complex data types

- gold Open Access which fosters wider collaboration and increased citations

- maximum visibility for your research: over $100 \mathrm{M}$ website views per year

At BMC, research is always in progress.

Learn more biomedcentral.com/submissions 